\title{
A Review of Seismic Response of Precast Structures
}

\author{
Ali Fallah ${ }^{1}$, Mohammadreza Vafaei ${ }^{2}$ and Sophia C. Alih ${ }^{3}$ \\ ${ }^{I}$ School of Civil Engineering, Faculty of Engineering, Universiti Teknologi Malaysia, 81310, Johor, Malaysia. \\ ${ }^{2}$ School of Civil Engineering, Faculty of Engineering, Universiti Teknologi Malaysia, 81310, Johor, Malaysia. \\ ${ }^{3}$ Institute of Noise and Vibration, School of Civil Engineering, Faculty of Engineering, Universiti Teknologi Malaysia, 81310, Johor, Malaysia. \\ ORCIDs: 0000-0001-9493-5242 (Ali Fallah), 0000-0002-9988-1842 (Mohammadreza) 0000-0001-5326-3670 (Sophia)
}

\begin{abstract}
Precast construction has received increasing attention during the past decades. Faster construction, higher quality, and relatively lower construction cost are among the main benefits of precast structures. However, poor seismic performance has been observed for precast structures during past earthquakes. This paper reviews the seismic-induced damage to the precast structures during past earthquakes and presents existing precast buildings' seismic vulnerability studies. The focus of this paper is on the seismic performance of beam-to-column precast joints. The review also includes the recent advancement in the development of wet and dry type precast beam-to-column connections.
\end{abstract}

Keywords - Precast building, Precast joint, Seismic damage, Dry connection, Wet connection

\section{INTRODUCTION}

Although the extensive network of underground tunnels indicates the application of precast structures in ancient Rome, the first precast concrete skeletal frame was built in the United Kingdom in 1897 [1]. In general, precast construction has gone through five different development stages. Developing years (1920-1940), mass production and standardization (1945-1970), lightweight and long-span construction (19702000), thermal mass period (2000 to date), and the automated period (a new era) are the five main development stages of precast concrete structures [1]. Nowadays, many different types of structures are built through the precast method. Bridges, culverts, retaining walls, foundations, schools, parking structures, and office buildings are a few examples of precast construction. One main reason for the widespread precast construction is cost saving. Precast construction allows for a convenient pre-tensioning of structural members, which significantly reduces the material and labor requirements compared with the cast-in-place construction. For example, compared with an in-situ construction method, the precast pre-stressed construction approach saved $55 \%$ of concrete quantity and $40 \%$ of reinforcing steel in the 33-story Ala Moana Building in Honolulu, Hawaii [2]. Another study showed that constructing a 10-story parking building, the direct cost required for a steel frame with the composite floor was $23.10 \%$ higher than the precast frame with precast concrete floor [3]. Precast construction is also a sustainable process. The concrete used in the precast construction has a high thermal mass; therefore, it absorbs and releases the heat slowly, which results in a long-term energy saving. Besides, precast structures require less material and produce less solid waste during the construction stages. A study conducted by Shen et al. [4] indicated that up to $70.70 \%$ of the cost of using cast-in-situ concreting could be saved by reusing precast slabs. Moreover, the precast construction resulted in higher quality and increased durability.

It has been shown that some factors have had a negative impact on the development of precast construction. For instance, the study conducted by Polat [5] showed that the level of standardization, lack of expertise, design issues, and the transportation cost reduced the share of precast concrete systems in the United States. Arditi et al. [6] reported the inadequate education in the structural and architectural design of precast structures as one of the main factors influencing precast structures' application. They also indicated that poor or inconsistent performance of precast structures during past earthquakes was another factor affecting precast technology in the United States. It should be mentioned that the seismic performance of precast structures has attracted the attention of many engineers and researchers during the past decades. For example, seismic performance of precast concrete columns [7-9], precast concrete wall [10-14], precast concrete diaphragms [15-18], precast frames [19-21], precast cladding [22,23], and precast joints [24-27] have been investigated. More detail of such investigations can be found in [28].

This review paper discusses the seismic performance of existing precast structures during past earthquakes, emphasizing on the seismic-induced damage to beam-tocolumn joints. The conducted experimental tests on precast buildings' seismic response have been reviewed, and the recent advancement in precast connections has been introduced.

\section{SEISMIC-INDUCED DAMAGE TO PRECAST STRUCTURES}

The construction industry has widely employed precast structures in many countries. As mentioned earlier, fast construction and erection, reduced construction cost, better construction quality, ease in quality assessment, continuous production even under the harsh environmental condition, and enhanced safety are benefits that a precast construction scheme offers. However, besides such desirable advantages, there are some drawbacks related to the precast structures. Similar to many structures that have not been designed for 
seismic actions [29-33], one main disadvantage of using precast structures is their vulnerability when subjected to strong lateral loads. Belleri et al. [34] investigated the seismic performance of seven one-story precast concrete structures not designed for seismic loads after the Emilia earthquake in Italy. They reported several local and global collapses. It was observed that the beam-to-column connections of studied structures mainly relied on friction without additional mechanical devices. They reported that the seismic vulnerability of the investigated precast structures was mostly related to the following factors:

i. Lack of mechanical connections between the precast structural elements led to the insufficient transfer of horizontal force from beams to columns. Consequently, it resulted in the loss of support and falling of beams, and then roof elements drop.

ii. Inadequate design and detailing of ductile elements

iii. Deficient and highly-flexible diaphragms

iv. Displacement incompatibility between structural and non-structural elements

Another investigation on the seismic vulnerability of precast industrial building in Italy after the Emilia earthquake was carried out by Magliulo et al. [35]. They reported that the vulnerability of friction beam-to-column connections was also due to the high friction coefficient $(c=0.35)$ suggested by past Italian codes. It should be mentioned that the current Italian code requires the use of mechanical devices as a connector between the precast elements [34]. Fig.1 shows one of the damaged precast concrete structures after the Emilia earthquake.

Seismic-induced damage to precast structures has also been reported in Turkey. One-story industrial buildings represent the most common form of precast construction in the northwest and central Turkey [36]. During the Marmara earthquake in 1999, many of precast buildings suffered severe damage. Posada and Wood [36] reported two types of damage to the precast buildings. The first type of damage was related to the formation of plastic hinges at the base of columns. However, the second type was due to the pounding of precast elements at the roof level. They also mentioned that in some under construction precast buildings, the roof girders rotated off their supports and resulted in partial collapse, as shown in Fig.2. As shown in Fig.3, approximately one-third of 318 single-story schools constructed by precast elements in the Kachchh region had roof collapses after January 26, 2001 Bhuj earthquake in India [37]. The inadequate connection between the roof panels, insufficient seating length, and weak anchorage of roof panels were the main reason for the observed damages. It was stated that the suitably of using precast buildings in countries with high seismicity like India requires more study.

Zhao et al. [38] investigated building structures' performance during the 12 May 2008 Wenchuan earthquake in China. They reported that the out-of-plane collapse of the clay brick gable was a common failure mode observed in the facade of many precast reinforced concrete industrial sheds. Investigations showed that although few precast buildings survived the earthquake, some were damaged significantly. Fig.4 shows one of the partially collapsed precast industrial buildings and the observed damage to its roof elements during the Wenchuan earthquake in China. Mitchell et al. [39] investigated precast parking structures' seismic performance after the Northridge earthquake in the USA. They reported that about $90 \%$ of the precast parking structure in southwest corner of Northridge Fashion Center was collapsed. Inadequacy of the diaphragm to properly transfer the loads through connections and ties was found to be one of the main reasons for the observed damage. They suggested that adequate connections between beams and columns and adequate load paths must be provided for lateral forces through floor and roof diaphragms in precast structures in seismic prone areas.

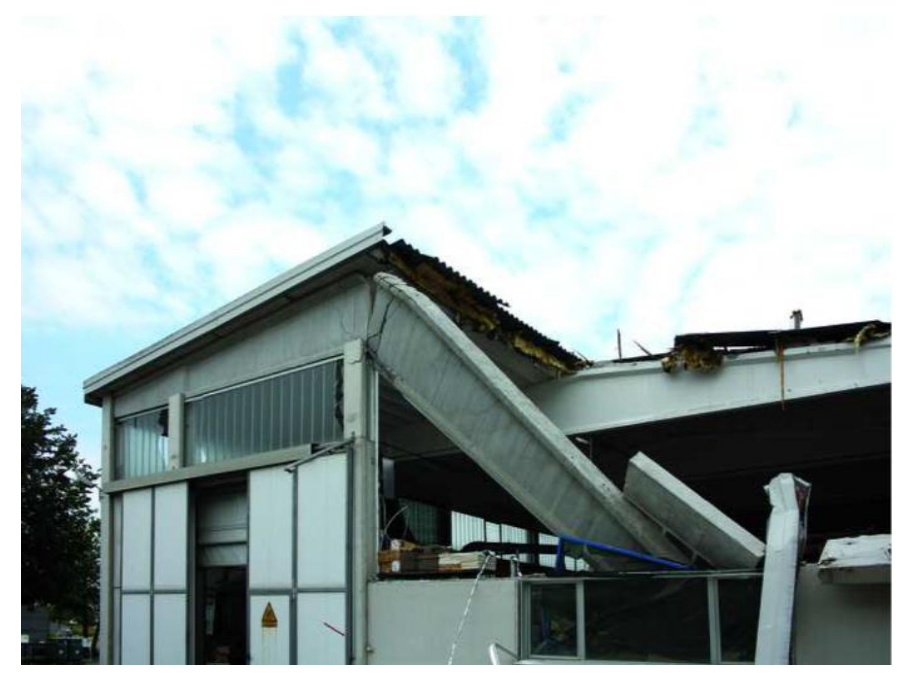

Fig 1 A damaged industrial precast building after Emilia earthquake in Italy

(reprinted from [34], Copyright ASCE, 2001)

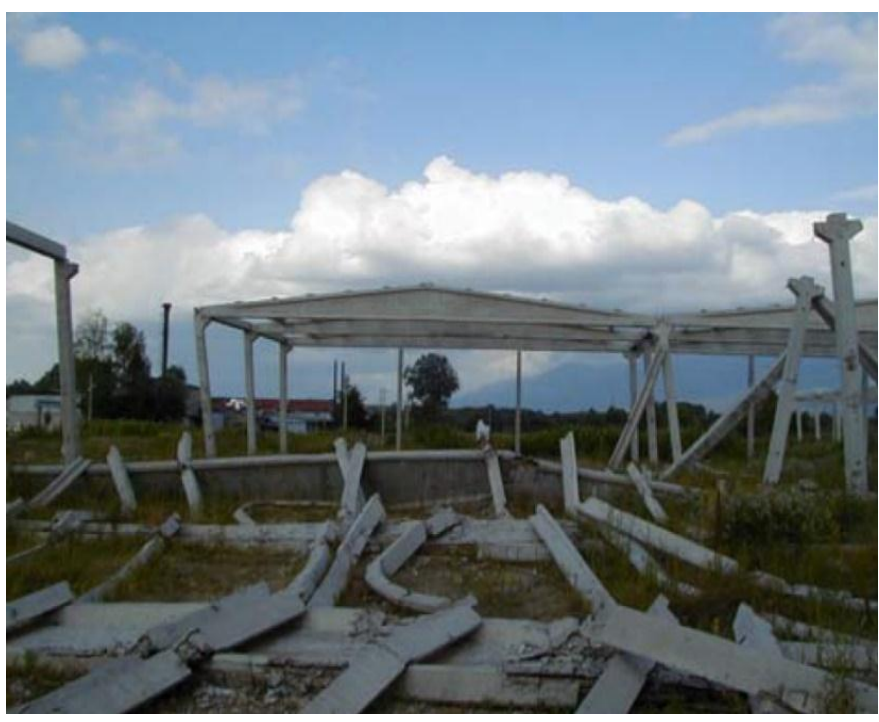

Fig 2 Seismic induced damage to precast industrial buildings in Turkey

(reprinted from [36] ) 


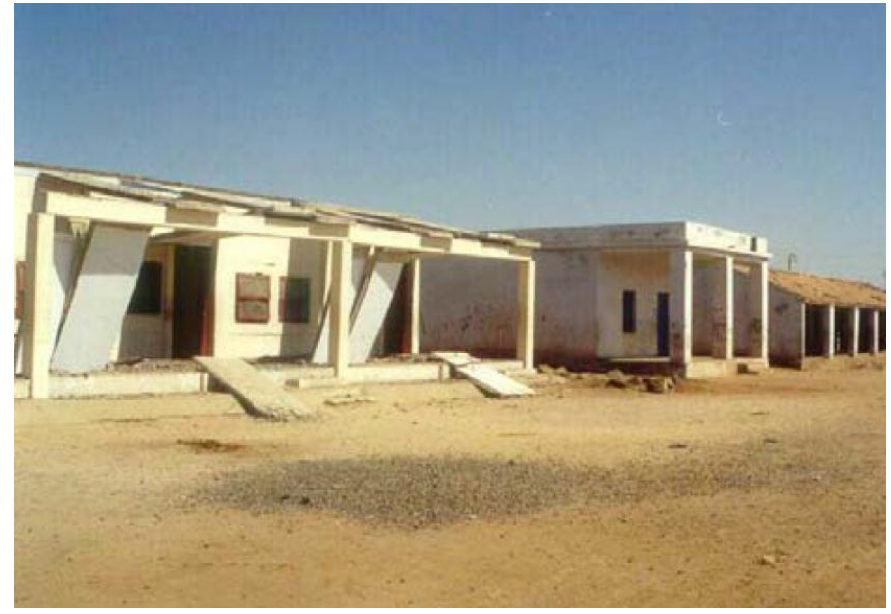

Fig 3 Seismic induced damage to the single-story precast schools in India (reprinted from [37], Copyright EERI, 2001)
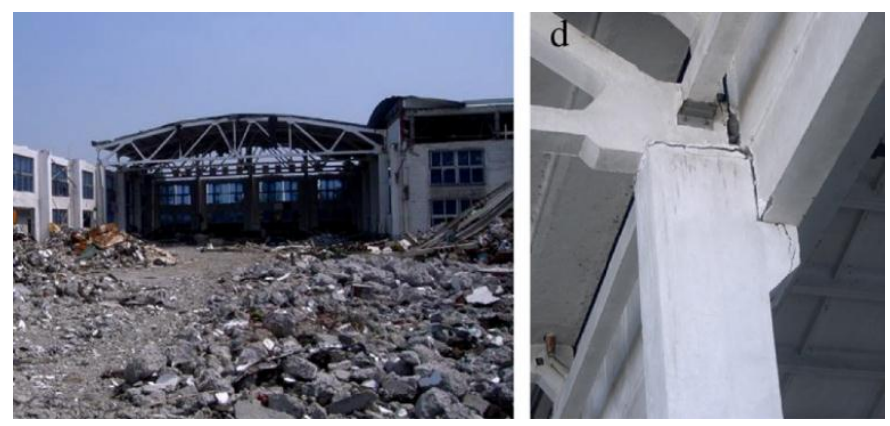

Fig 4 A damaged precast industrial building in China (reprinted from [38], Copyright Elsevier, 2009)

\section{NUMERICAL INVESTIGATIONS PERFORMANCE BUILDINGS \\ AND EXPERIMENTAL ON THE SEISMIC OF EXISTING PRECAST}

During past decades, the seismic performance of existing precast structures has been investigated by many researchers. Kothari et al. [40] subjected one monolithic portal frame and two portal frames with a cleat angle and reinforced concrete (RC) corbel connections to lateral loads. They reported that the portal frame with cleat angle showed almost similar behavior to the monolithic portal frame. In another study, the seismic performance of precast single-story frames with a pinned connection was investigated through a series of shake table tests [41]. A comparison was made between the shake table test results and the results of a pure shear cyclic test on the specimens with the same geometry. It was observed that the shake table tests led to less damage to the specimens when compared with the pure shear test. Results also indicated that the pinned connections were able to accommodate large rotations. Besides, it was reported that the vertical component of earthquakes had an insignificant effect on the seismic response of tested specimens.

Ercolino et al. [42] investigated the seismic vulnerability of precast single-story buildings designed according to the current Italian seismic code through numerical simulations.
They concluded that the buildings were safe against the collapse mainly because of their relatively high structural overstrength factor. A seismic fragility model for the Italian $\mathrm{RC}$ precast buildings was proposed by Casotto et al. [43] in order to be used in earthquake loss estimation and seismic risk assessment. A good agreement with preliminary empirical fragility functions based on field data was observed. The effects of different variables on the behavior of precast structures with dowel pin connections were investigated by Clementi et al. [44]. The obtained results indicated the significant role of the connection between members. In another study, the seismic behavior of existing precast structures built in Italy between the 1950s and the 1970s was investigated by Magliulo et al. [35]. The obtained results from nonlinear dynamic analyses indicated that the beam-tocolumn connections could fail under the medium intensity earthquakes, which could result in severe damage to the precast structures.

A full-scale 3-story precast concrete building was subjected to the pseudo-dynamic tests by Negro et al. [45]. The tests included the behavior of traditional as well as innovative connections. Besides, the effect of shear walls on the seismic response of the building was studied. It was observed that the conventional shear connectors (i.e., dowel bars) experienced large deformations under the design level earthquake. It was also reported that the precast walls were able to decrease the inter-story drift ratios to the required limit states. Sucuoglu [46] showed that precast structures could have a similar response to the monolithic counterparts when their beam fixity factors were above 0.8. It was also indicated that bending moments in beams were not sensitive to the rigidity of connections under the applied lateral loads.

\section{RECENT ADVANCMENT IN PRECAST BEAM-TO- COLUMN CONNECTIONS}

Precast elements are connected to each other by two different approaches: a dry or wet connection. Compared to the wet connections, the dry connections have a higher cost and need experienced workers to install them [47]. On the other hand, dry connections can be installed faster and have higher quality. In the following sections, the advancement in the dry and wet connections have been presented.

\section{IV.I DRY CONNECTIONS}

A hybrid precast beam-to-column connection was proposed by Ghayeb et al. [48]. As can be seen from Fig. 5 the connection makes use of protruding steel plates embedded at the end of the precast beam connect it to a precast column. It can also be seen that the precast column comprises two steel tubes with a circular hollow section embedded at the top and bottom ends of the precast column. The embedded inside steel plates of the precast beam are connected to the steel tubes through bolts and nuts. To evaluate the proposed connection's seismic performance, it was subjected to a cyclic loading, and the obtained results were compared with a monolithic reinforced concrete joint. The proposed connection exhibited stable load-displacement cycles, and its energy dissipation 
was higher than the monolithic specimen. They concluded that the proposed connection had a satisfactory response against seismic loads.

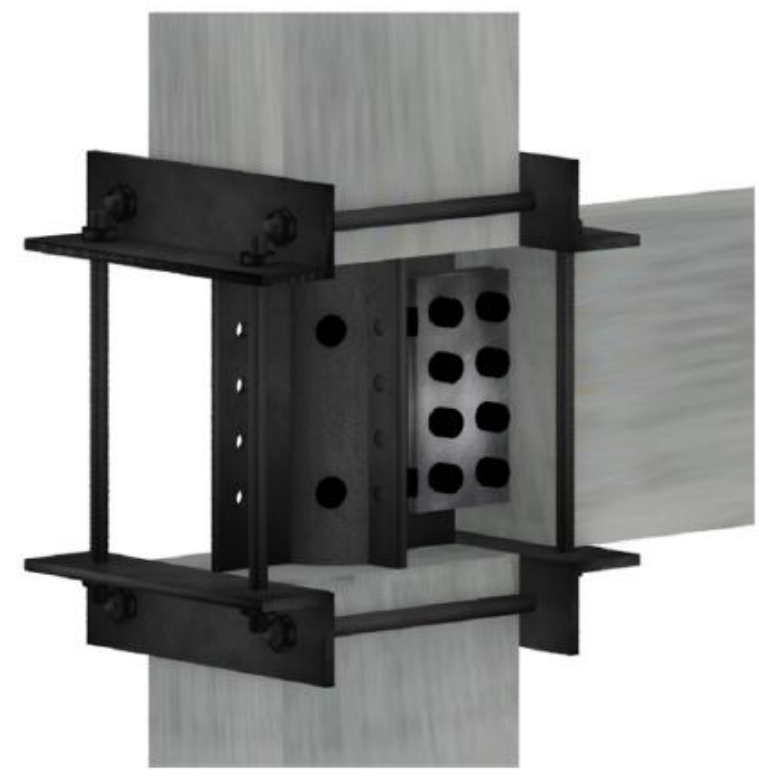

Fig 5 A hybrid precast beam-to-column connection (reprinted from [48], Copyright Elsevier, 2017)

Bahrami and Madhkhan [49] proposed an inverted E corbel for precast beam-to-column connections. As shown in Fig. 6 the proposed connection has an E-shaped steel corbel connected to the column by welding the steel plates of the corbel to four vertical bars embedded on the column's surface. The beams' bottom part is connected to the column through corbel and two threaded bars and nuts. The upper side of the beam is connected to the column by two threaded bars that pass through the beam's stirrups and two holes made in the column. It was reported that the proposed connection had a comparable load-bearing and deformation capacities to that of a monolithic specimen. However, its energy dissipation capacity was less than the monolithic specimen.

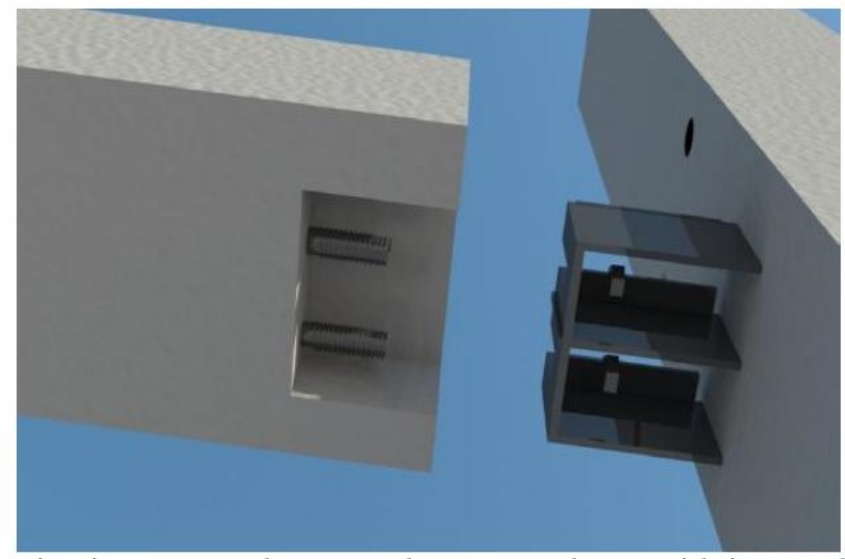

Fig 6 An inverted E corbel for precast beam-to-column connection (reprinted from [49], Copyright Springer, 2017)

Shufeng et al. [50] proposed a precast beam-to-column connection with an endplate. As Fig. 7 shows the endplate is connected to the precast beam through the welding of two anchor plates that are located at the top and bottom of the precast beam. The precast beam is connected to the precast column by six high-strength pre-stressed bolts that pass through the column. The proposed connection was subjected to the quasi-static cyclic loading, and its hysteretic curve was investigated. The displacement ductility ratio of the connection varied between 2.6 to 3.4. Besides, a satisfactory energy dissipation capacity was observed for the proposed connection.

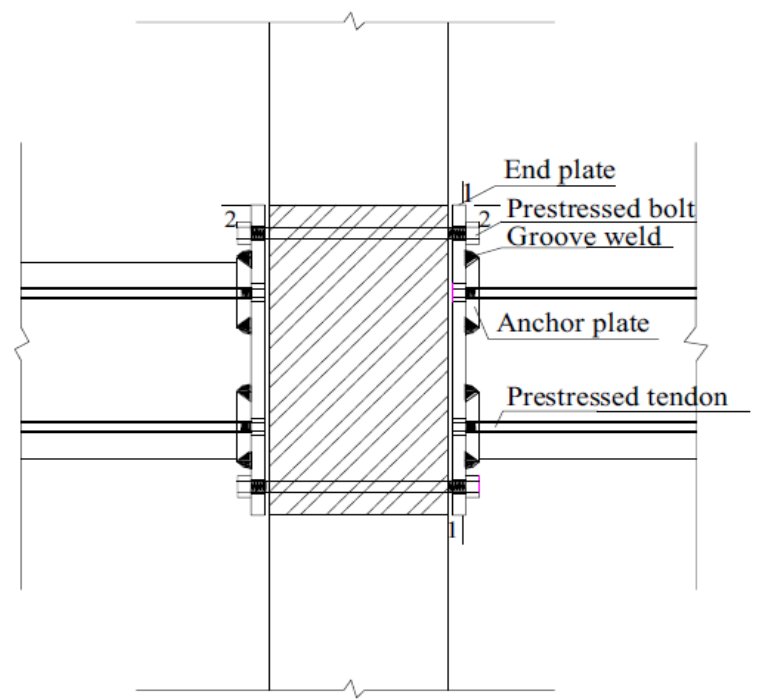

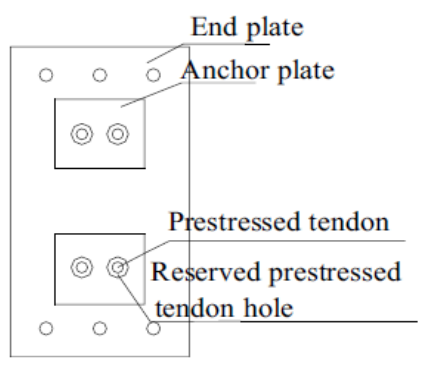

$1-1$

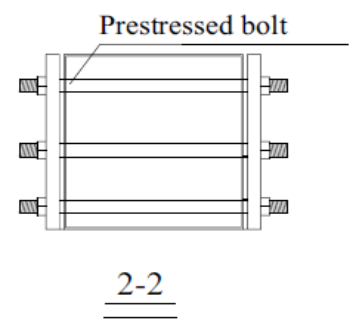

Fig 7 A confined concrete beam-to-column connection with end plates (reprinted from [50], Copyright Elsevier, 2017) 
In another study, Aninthaneni et al. [51] proposed a demountable precast beam-to-column connection using a steel endplate. As shown in Fig. 8 the endplate is welded to embedded steel plates located at the top and bottom of a precast beam. Besides, the proposed connection takes advantage of gusset plates at the top and bottom of the precast beam to increase the connection's rotational rigidity and moment capacity. The precast beam is connected to the precast column through threaded rods that pass through steel ducts embedded in the precast column. The obtained results from cyclic tests indicated that the proposed connection's hysteretic behavior is similar to that of monolithic reinforced connecter connection. Relatively better energy dissipation was also observed for the proposed connection when it was compared with a sub-assembly of a ductile connector.

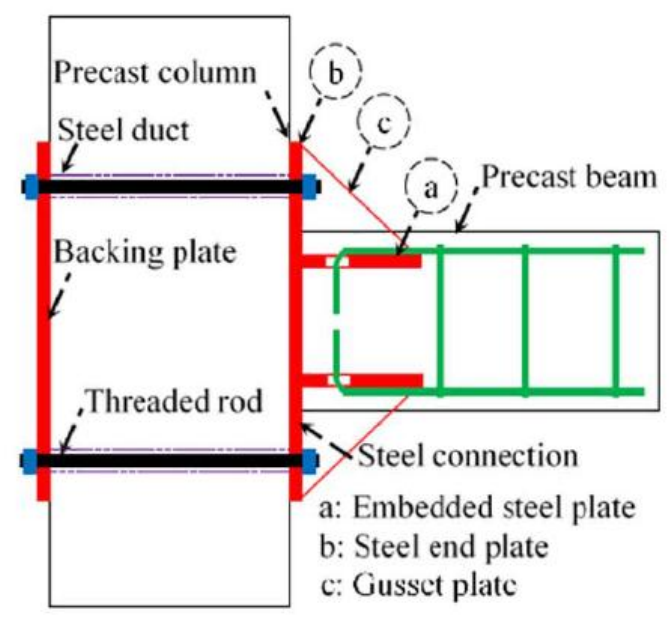

\section{(a) Schematic layout of the connection}

Fig 8 A demountable precast beam-to-column connection with an end plate (reprinted from [51], Copyright Elsevier, 2018)
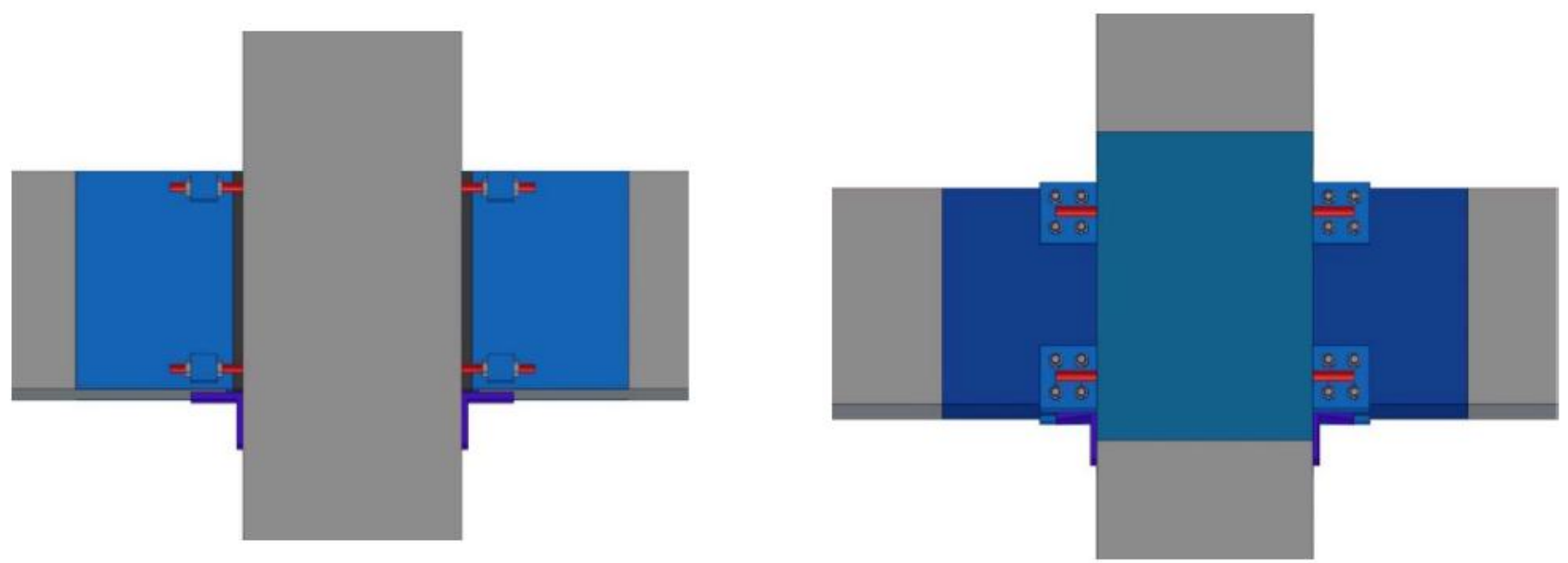

Fig 9 A precast pre-stressed reinforced concrete beam-to-column joint (reprinted from [52], Copyright Elsevier, 2018)

Wang et al. [52] introduced a pre-stressed precast beam-tocolumn connection that uses steel angles to transfer the shear force from the precast beams to the precast column (see Fig. 9). The precast beam's bending moment is transferred to the column through unbounded post-tensioned strands and mild steel bars. The post-tensioned strands are located at the centerline of beams, and the mild steel bars are placed at the top and bottom of beams. The post-tensioned strands are designed to remain elastic during seismic events, while the mild steel bars are allowed to yield and dissipate the input energy. The quasi-static cyclic test results indicated that the post-tensioned strands were able to limit the residual deformation through their self-centering characteristic. Besides, it was reported that the damaged connection could be easily repaired, and the repaired connection also exhibited excellent performance.

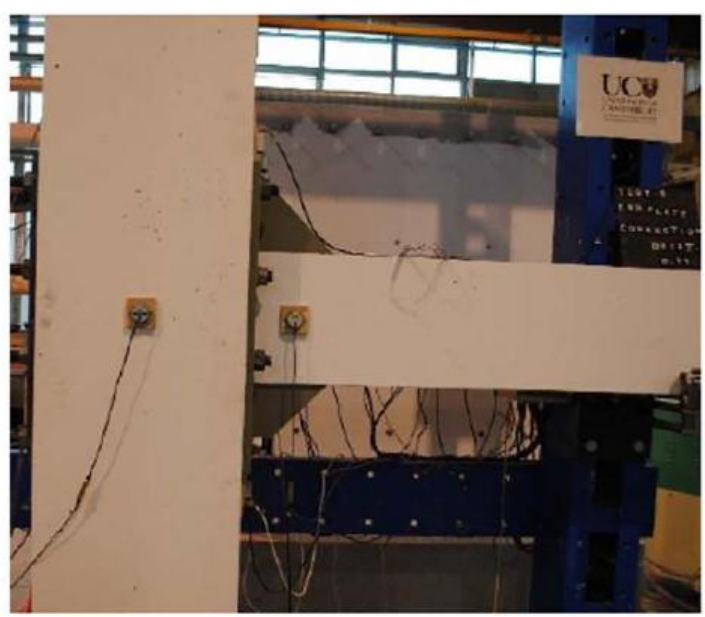

(b) A sub-assembly with the end plate connection

\section{Fig A demountable precast beam-t0-column connection with an end plate (reprinted from [51], Copyright Elsevier, 2018)}




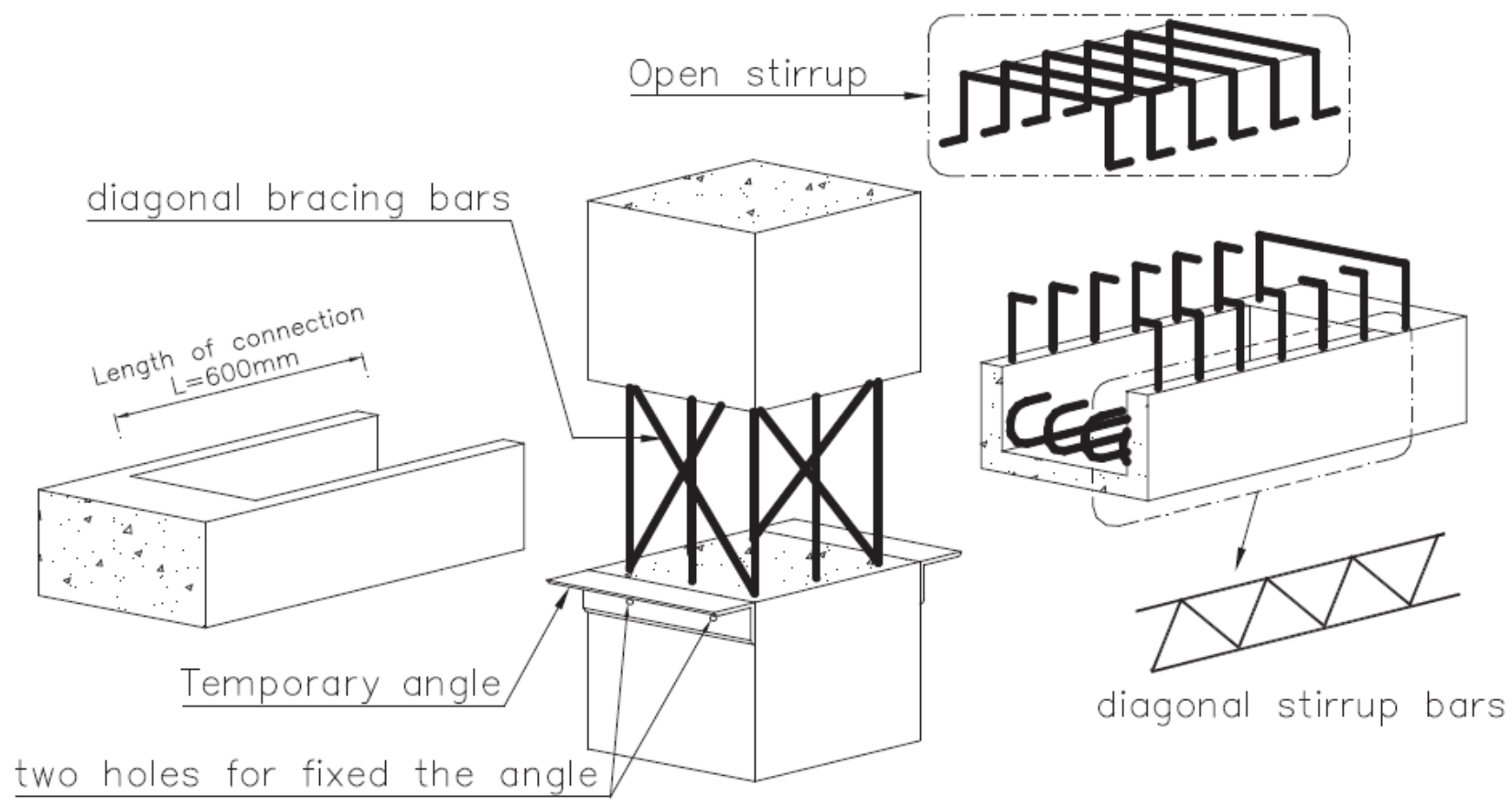

Fig 10 A new ductile moment-resisting connection for precast concrete frames (reprinted from [53], Copyright Elsevier, 2018)

\section{IV.II WET CONNECTIONS}

Parastesh et al. [53] proposed a wet connection for the precast beam-to-column connections with high ductility. As shown in Fig. 10 a free space is provided in the precast column that allows the precast beam to connect to the column. Four diagonal bars located at the free space of the column provides adequate stability during the installation process. At the connection zone, the precast beam has a hollow U-shaped cross-section. While the bottom longitudinal bars of the precast beams are spliced at the connection zone, the upper bars are continuous through the joint. The connection makes use of diagonal and U-shaped stirrups to enhance the shear strength of the connection before casting the concrete. Results of cyclic tests indicated that the proposed connection had higher initial stiffness and flexural strength compared to monolithic sections. Moreover, up to $46 \%$, higher ductility was observed for the proposed connection when it was compared to the monolithic specimens.

Lu et al. [54] employed Engineered Cementitious Composite (ECC) to developed a new type of wet beam-to-column connection. In the proposed connection, the bottom reinforcing bars are spliced while those at the top are continuous. U-shaped bars are used at the bottom of the precast beam to connect the precast beams' hooked bars at both sides of the column. A high strength ECC is used to fill the free space of the precast column. Results of cyclic tests indicated that the proposed connection had similar hysteretic behavior, energy dissipation, and strength degradation to that of a monolithic specimen.

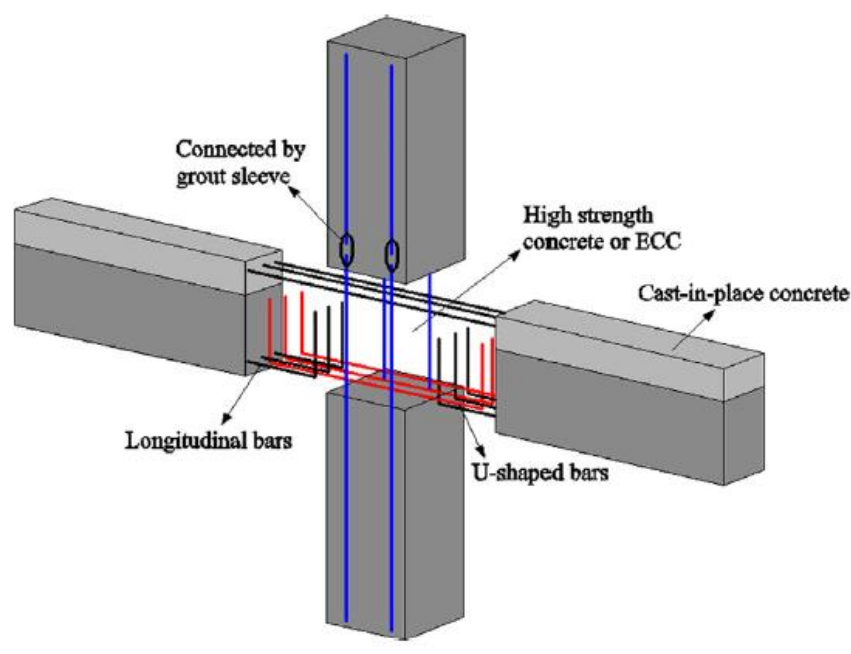

Fig 11 A new connection for precast concrete frames (reprinted from [54], Copyright Elsevier, 2018)

Choi et al. [55] used steel connectors and ECC to develop a ductile beam-to-column connection. In the proposed connection, bolting steel tubes and steel plates are embedded in the precast column and beams, respectively. The precast beam is connected to the column through the embedded steel plates and bolts. Besides, ECC is poured in the free space of the precast column and beams. The cyclic test results indicated that the proposed connection had 15\% larger ultimate strength compared with the monolithic specimens. It was also concluded that the proposed connection satisfied the requirement prescribed in the ACI structural guideline and could be used in seismic prone countries. 


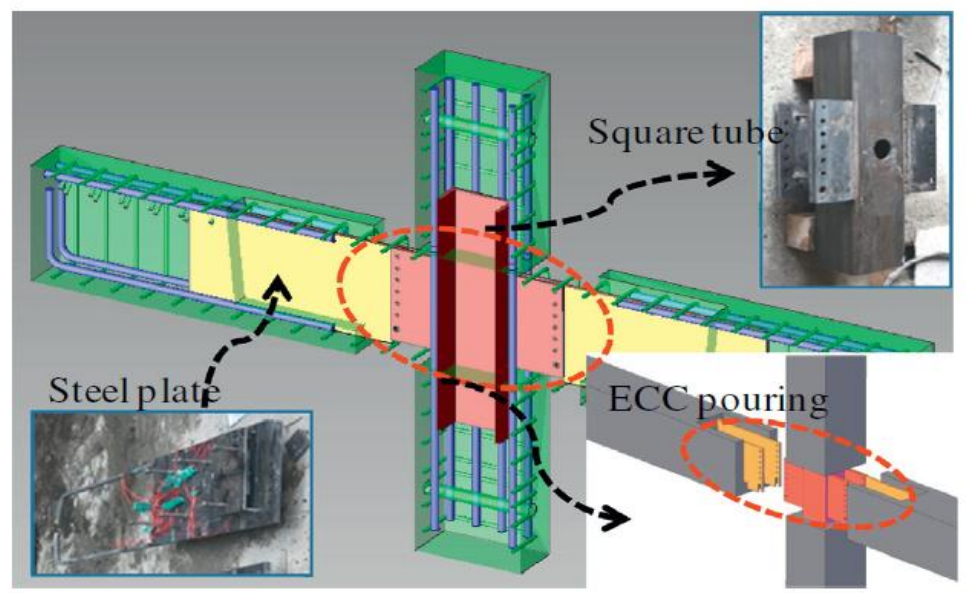

Fig 12 A new connection for precast concrete frames (reprinted from [55], Copyright Elsevier, 2013)

Girgin et al. [56] investigated the seismic performance of hybrid beam-to-column connections that employed welded components. As can be seen from Fig. 13, before casting the precast beam, its bottom longitudinal bars are welded to an endplate, which rests on a corbel. The top longitudinal bars are continuous and are placed to designated gaps in joint panels. Results of cyclic tests indicated that specimens with un-bonded lengths on the longitudinal bars had a gradual strength degradation and a similar damage index to the monolithic specimen.

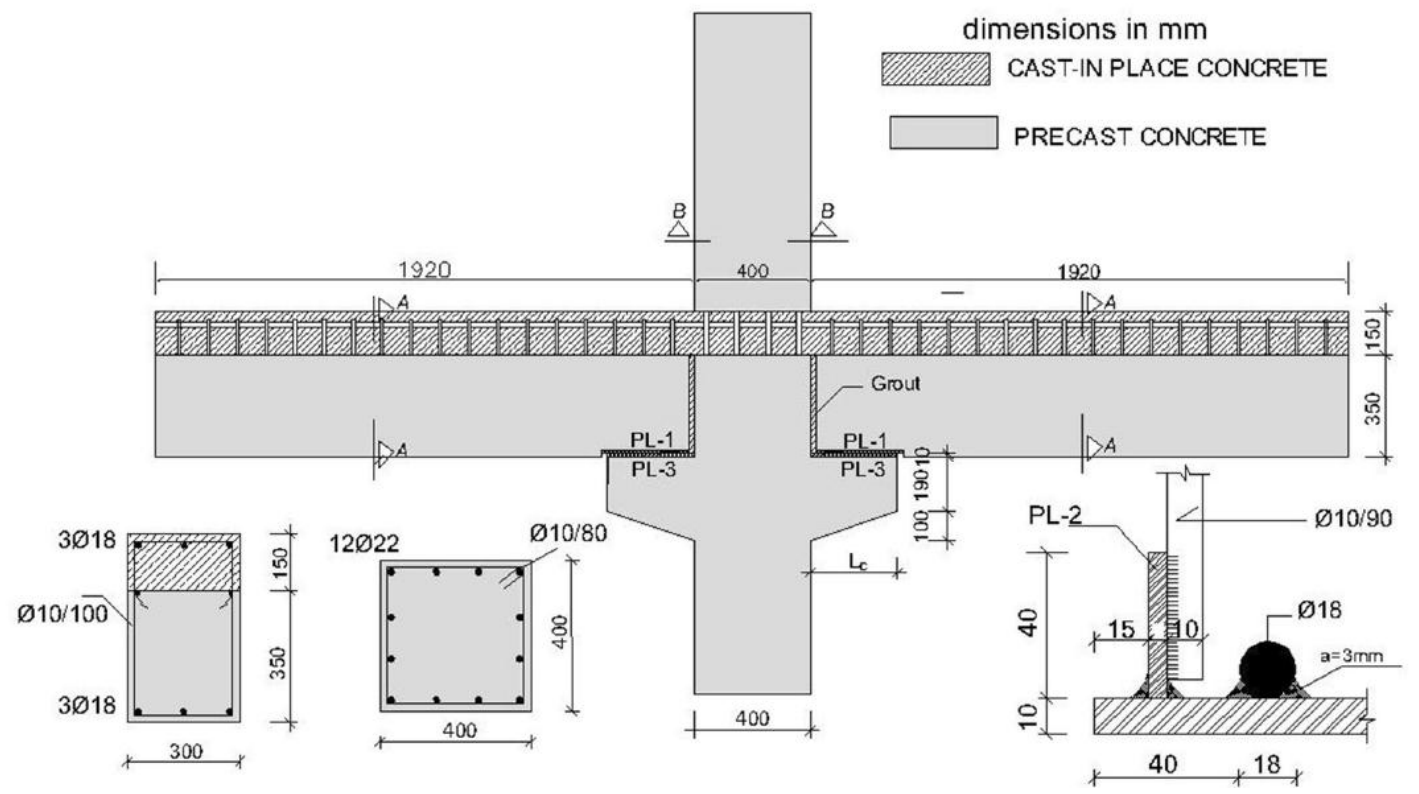

Fig 13 A hybrid beam-to-column connection (reprinted from [56], Copyright Girgin, Sadik Can, Misir, Ibrahim Serkan, Kahraman, Serap, 2017)

Ketiyot and Hansapinyo [57] proposed a new beam-to-column connection that used a T-section embedded in the bottom of the precast beam. The T-section is protruded from the end of the precast beam and connects the beam to the precast column (see Fig. 14). It should be mentioned that a steel plate which is welded to the protruded T-sections connects the precast beams located at both sides of the column to each other. On top, the precast beams are connected by reinforcing bars. Results of cyclic tests indicated that the specimens' ultimate strength with the proposed precast connection was lower than the monolithic section. It was suggested to employ a longer lap splice length to improve the seismic performance of the connection. 


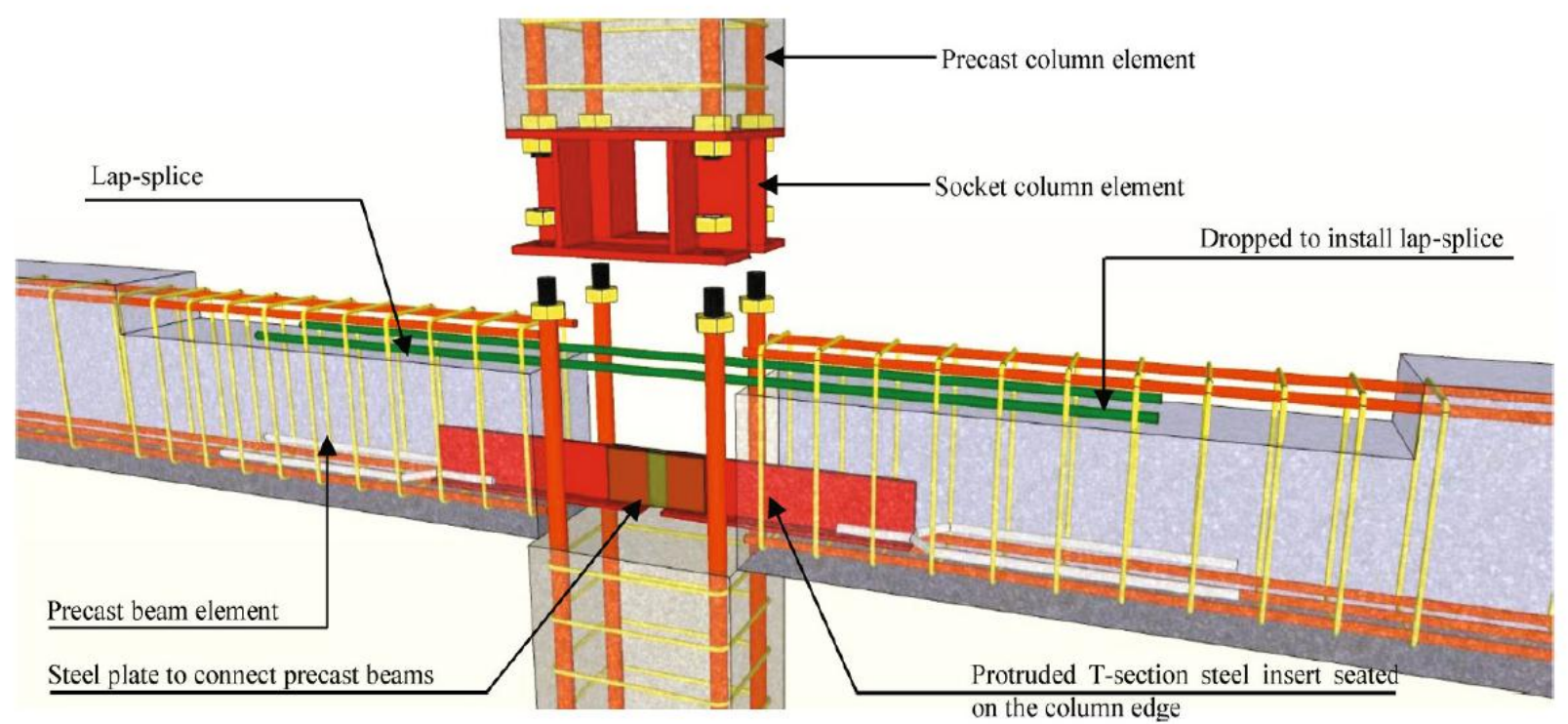

Fig 14 A beam-to-column precast connection with T-section (reprinted from [57], Copyright Springer, 2013)

Yan et al. [58] proposed a precast connection that employed grout sleeves. In the proposed connection, two types of grout sleeves are used to connect reinforcing bars. For beams, full grout sleeves are employed while for columns, half grout sleeves are used. The full grout sleeves are longer than the half grout sleeves and connect reinforcing bars to each other through grouting. However, the half grout sleeves use screw thread at one side and grouting at another side to connect reinforcing bars to each other. The results of the cyclic test showed that the proposed connection behaved similarly to the monolithic specimen. However, different crack patterns and deformation in the joint were observed. They also reported that the slippage of longitudinal bars occurred in the core region of the joint.

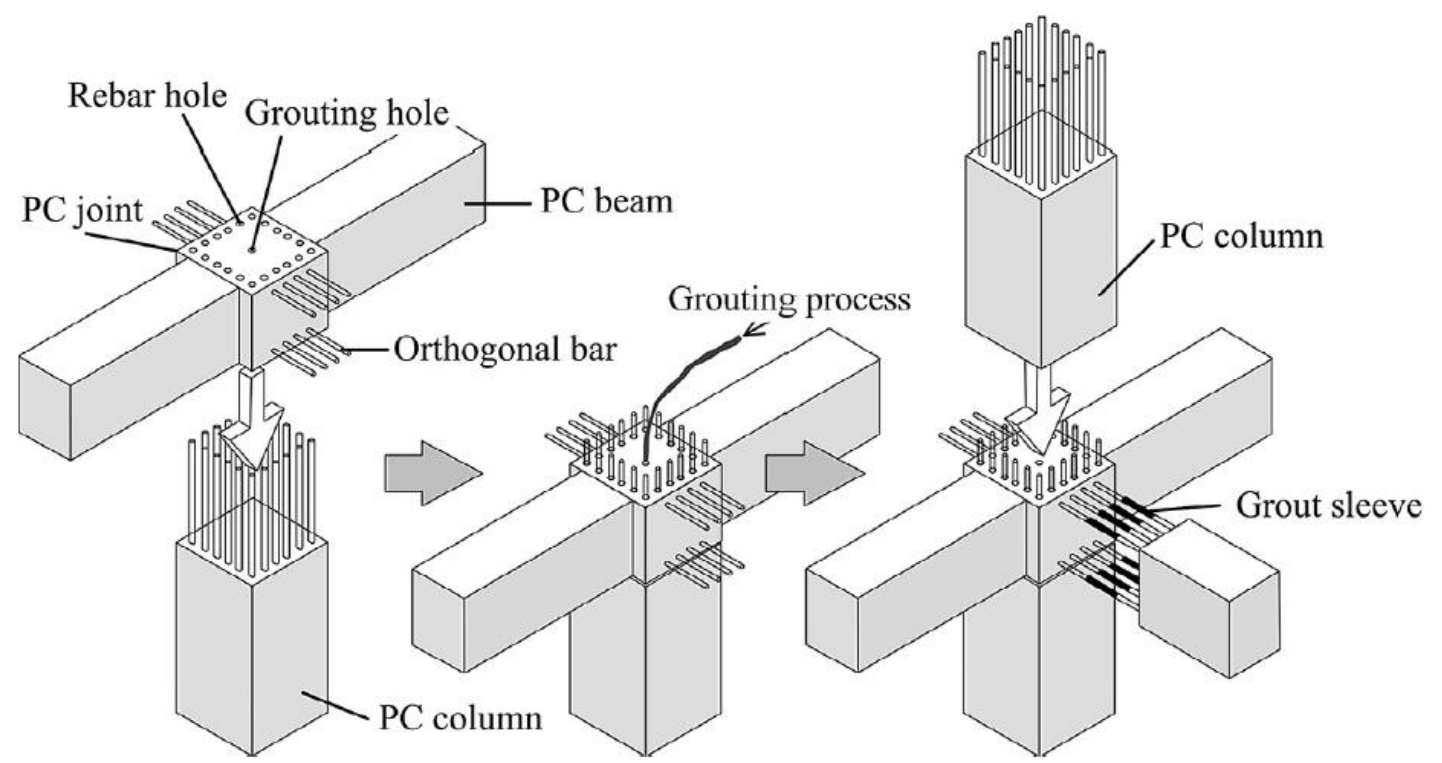

Fig 15 A beam-to-column precast connection with grout sleeves (reprinted from [58], Copyright Elsevier, 2018) 


\section{CONCLUSION}

This paper presented a review of the seismic performance of precast structures when subjected to real earthquakes. Besides, studies investigating the seismic response of existing precast buildings through experimental works and numerical studies were reviewed. The recent advances in the development of dry and wet precast connections were also illustrated. A literature review shows that the majority of existing precast structures have been vulnerable to seismic actions. As reported by many researchers, the connection failure has been the main reason for the structural collapse of many precast structures. The vulnerability of existing precast buildings designed and constructed without considering seismic actions has also been demonstrated through many experimental works and numerical studies. However, the strengthening of substandard precast connections has not been well addressed in the previous works and needs further investigations.

The diffused and lumped plasticity models have been successfully used to study single-story precast buildings' seismic response. However, such models' accuracy for nonlinear dynamic analysis of multi-story precast buildings and bridges needs to be investigated. It is also noteworthy that precast structures' seismic vulnerability studies have been limited to a few countries (like Turkey, Italy, and the USA). It is of great interest and importance to investigate precast buildings' seismic vulnerability in other countries that use different types of connections. Such investigations can enhance our understanding of the seismic response of different precast connections and, consequently, help us find a better solution for the upgrade or strengthening of deficient joints. It should also be mentioned that the majority of existing studies have focused on single-story precast industrial buildings, and limited studies have investigated the seismic response of significant precast buildings like hospitals. The conducted literature review also emphasizes the critical role of precast joints during seismic events and highlights that more ductile precast connections need to be developed.

During past decades many innovative precast beam-to-column connections have been developed. The majority of such connections have shown an acceptable seismic performance. However, in many cases, the developed connections are complex, and their installation requires experienced workers. Moreover, the construction process in many developed wet connections takes a long time, and some need temporary scaffolding or support. The fabrication cost of the developed connections is another issue that has not been addressed in previous studies.

\section{ACKNOWLEDGEMENTS}

The authors would like to thank the provided supports by Universiti Teknologi Malaysia (UTM). The financial support from the Ministry of Higher Education of Malaysia through the RUG votes of $16 \mathrm{~J} 24$ and 4L705 are acknowledged

\section{REFERENCES}

[1] K.S. Elliott, Historical and Chronological Development of Precast Concrete Structures, in: Mod. Mech. Ind. Concr. Struct., John Wiley \& Sons, Ltd, Chichester, UK, 2017: pp. 1-60. https://doi.org/10.1002/9781118876503.ch1.

[2] A.A. Yee, Social and environmental benefits of precast concrete technology, PCI J. 46 (2001) 14-19. https://doi.org/10.15554/pcij.05012001.14.19.

[3] U.D. Dabhade, N.A. Hedaoo, L.M. Gupta, G.N. Ronghe, Time and cost evaluation of construction of steel framed composite floor with precast concrete floor structure, in: 2009 26th Int. Symp. Autom. Robot. Constr. ISARC 2009, International Association for Automation and Robotics in Construction I.A.A.R.C), 2009: pp. 139-148. https://doi.org/10.22260/isarc2009/0071.

[4] L. yin Shen, V.W. yan Tam, C. yang Li, Benefit analysis on replacing in situ concreting with precast slabs for temporary construction works in pursuing sustainable construction practice, Resour. Conserv. Recycl. $\quad 53 \quad$ (2009) $145-148$. https://doi.org/10.1016/j.resconrec.2008.11.001.

[5] G. Polat, Factors Affecting the Use of Precast Concrete Systems in the United States, J. Constr. Eng. Manag. $134 \quad$ (2008) 169-178. https://doi.org/10.1061/(ASCE)07339364(2008)134:3(169).

[6] D. Arditi, U. Ergin, S. Günhan, Factors Affecting the Use of Precast Concrete Systems, J. Archit. Eng. 6 (2000) 79-86. https://doi.org/10.1061/(ASCE)10760431(2000)6:3(79).

[7] R. Yamashita, D.H. Sanders, Seismic performance of precast unbonded prestressed concrete columns, ACI Struct. J. $106 \quad$ (2009) 821-830. https://doi.org/10.14359/51663183.

[8] J.F. Rave-Arango, C.A. Blandón, J.I. Restrepo, F. Carmona, Seismic performance of precast concrete column-to-column lap-splice connections, Eng. $\begin{array}{llll}\text { Struct. } & 172 & \text { (2018) 687-699. }\end{array}$ https://doi.org/10.1016/j.engstruct.2018.06.049.

[9] M.J. Ameli, J.E. Parks, D.N. Brown, C.P. Pantelides, Seismic evaluation of grouted splice sleeve connections for reinforced precast concrete columnto-cap beam joints in accelerated bridge construction, $\begin{array}{lllll}\text { PCI } & \text { J. } & 60 & \text { (2015) } & 80-103 .\end{array}$ https://doi.org/10.15554/pcij.03012015.80.103.

[10] T. Holden, J. Restrepo, J.B. Mander, Seismic Performance of Precast Reinforced and Prestressed Concrete Walls, J. Struct. Eng. 129 (2003) 286-296. https://doi.org/10.1061/(ASCE)07339445(2003)129:3(286).

[11] Y. Kurama, R. Sause, S. Pessiki, L.W. Lu, Lateral load behavior and seismic design of unbonded posttensioned precast concrete walls, ACI Struct. J. 96 (1999) 622-632. https://doi.org/10.14359/700. 
International Journal of Engineering Research and Technology. ISSN 0974-3154, Volume 13, Number 10 (2020), pp. 2694-2705

(C) International Research Publication House. https://dx.doi.org/10.37624/IJERT/13.10.2020.2694-2705

[12] Y.C. Kurama, Seismic design of unbonded posttensioned precast concrete walls with supplemental viscous damping, ACI Struct. J. 97 (2000) 648-658. https://doi.org/10.14359/7431.

[13] Y. Kurama, S. Pessiki, R. Sause, L.W. Lu, Seismic behavior and design of unbonded post-tensioned precast concrete walls, PCI J. 44 (1999) 72-89. https://doi.org/10.15554/pcij.05011999.72.89.

[14] F.J. Perez, R. Sause, S. Pessiki, Analytical and Experimental Lateral Load Behavior of Unbonded Posttensioned Precast Concrete Walls, J. Struct. Eng. 133 (2007) 1531-1540. https://doi.org/10.1061/(ASCE)07339445(2007)133:11(1531).

[15] R.B. Fleischman, K.T. Farrow, Seismic design recommendations for precast concrete diaphragms in long floor span construction, PCI J. 48 (2003) 46-62. https://doi.org/10.15554/pcij.11012003.46.62.

[16] R.B. Fleischman, J.I. Restrepo, C.J. Naito, R. Sause, D. Zhang, M. Schoettler, Integrated Analytical and Experimental Research to Develop a New Seismic Design Methodology for Precast Concrete Diaphragms, J. Struct. Eng. 139 (2013) 1192-1204. https://doi.org/10.1061/(ASCE)ST.1943541X.0000734.

[17] R.B. Fleischman, G. Wan, Appropriate Overstrength of Shear Reinforcement in Precast Concrete Diaphragms, J. Struct. Eng. 133 (2007) 1616-1626. https://doi.org/10.1061/(ASCE)07339445(2007)133:11(1616).

[18] R. Fleischman, C.J. Naito, J.I. Restrepo, Seismic Design Methodology for Precast Concrete Diaphragms Part 1: Design Framework, Artic. Pci J. (2005).

https://doi.org/10.15554/pcij.09012005.68.83.

[19] H. Sucuoğ lu, Inelastic seismic response of precast concrete frames with constructed plastic hinges, Comput. Struct. $56 \quad$ (1995) 121-131. https://doi.org/10.1016/0045-7949(94)00536-C.

[20] M.J.N. Priestley, J.R. Tao, Seismic Response of Precast Prestressed Concrete Frames With Partially Debonded Tendons, PCI J. 38 (1993) 58-69. https://doi.org/10.15554/pcij.01011993.58.69.

[21] E. Brunesi, R. Nascimbene, D. Bolognini, D. Bellotti, Experimental investigation of the cyclic response of reinforced precast concrete framed structures, PCI J. $60 \quad$ (2015) 57-79. https://doi.org/10.15554/pcij.03012015.57.79.

[22] P. Negro, M. Lamperti Tornaghi, Seismic response of precast structures with vertical cladding panels: The SAFECLADDING experimental campaign, Eng. Struct. $\quad 132 \quad$ (2017) 205-228. https://doi.org/10.1016/j.engstruct.2016.11.020.

[23] A. Belleri, M. Torquati, A. Marini, P. Riva, Horizontal cladding panels: in-plane seismic performance in precast concrete buildings, Bull.
Earthq. Eng. $14 \quad$ (2016) 1103-1129. https://doi.org/10.1007/s10518-015-9861-8.

[24] E. Brunesi, R. Nascimbene, Experimental and numerical investigation of the seismic response of precast wall connections, Bull. Earthq. Eng. 15 (2017) 5511-5550. https://doi.org/10.1007/s10518017-0166-y.

[25] Y. Liu, X. Li, X. Zheng, Z. Song, Experimental study on seismic response of precast bridge piers with double-grouted sleeve connections, Eng. Struct. 221 (2020) 111023. https://doi.org/10.1016/j.engstruct.2020.111023.

[26] E. Brunesi, R. Nascimbene, S. Peloso, Evaluation of the Seismic Response of Precast Wall Connections: Experimental Observations and Numerical Modeling, J. Earthq. Eng. 24 (2020) 1057-1082. https://doi.org/10.1080/13632469.2018.1469440.

[27] A. Titi, F. Biondini, G. Toniolo, Seismic assessment of existing precast structures with dry-friction beamto-column joints, Bull. Earthq. Eng. 16 (2018) 2067 2086. https://doi.org/10.1007/s10518-017-0271-y.

[28] Y.C. Kurama, S. Sritharan, R.B. Fleischman, J.I. Restrepo, R.S. Henry, N.M. Cleland, S.K. Ghosh, P. Bonelli, Seismic-Resistant Precast Concrete Structures: State of the Art, J. Struct. Eng. 144 (2018) 03118001 https://doi.org/10.1061/(ASCE)ST.1943541X.0001972.

[29] S.C. Alih, M. Vafaei, Performance of reinforced concrete buildings and wooden structures during the 2015 Mw 6.0 Sabah earthquake in Malaysia, Eng. Fail. Anal. $102 \quad$ (2019) 351-368. https://doi.org/10.1016/j.engfailanal.2019.04.056.

[30] N.H.F.A. Halim, S.C. Alih, M. Vafaei, M. Baniahmadi, A. Fallah, Durability of fibre reinforced polymer under aggressive environment and severe loading: A review, Int. J. Appl. Eng. Res. 12 (2017) 12519-12533.

[31] A. Pabarja, M. Vafaei, S. C. Alih, M.Y. Md Yatim, S.A. Osman, Experimental study on the efficiency of tuned liquid dampers for vibration mitigation of a vertically irregular structure, Mech. Syst. Signal Process. $114 \quad$ (2019) 84-105. https://doi.org/10.1016/j.ymssp.2018.05.008.

[32] F.R. Mansour, S.A. Bakar, M. Vafaei, S.C. Alih, Effect of substrate surface roughness on the flexural performance of concrete slabs strengthened with a steel-fiber-reinforced concrete layer, PCI J. 62 (2017) 78-89. https://doi.org/10.15554/pcij62.1-02.

[33] H. Shad, A. Adnan, H.P. Behbahani, M. Vafaei, Efficiency of TLDs with bottom-mounted baffles in suppression of structural responses when subjected to harmonic excitations, Struct. Eng. Mech. 60 (2016) 131-148. https://doi.org/10.12989/sem.2016.60.1.131.

[34] A. Belleri, E. Brunesi, R. Nascimbene, M. Pagani, P. 
Riva, Seismic Performance of Precast Industrial Facilities Following Major Earthquakes in the Italian Territory, J. Perform. Constr. Facil. 29 (2015) 04014135. https://doi.org/10.1061/(ASCE)CF.19435509.0000617.

[35] G. Magliulo, G. Fabbrocino, G. Manfredi, Seismic assessment of existing precast industrial buildings using static and dynamic nonlinear analyses, Eng. $\begin{array}{llll}\text { Struct. } & 30 & \text { (2008) } & \text { 2580-2588. }\end{array}$ https://doi.org/10.1016/j.engstruct.2008.02.003.

[36] M. Posada, S. L. Wood, Seismic performance of precast industrial buildings in Turkey, in: 7th US Natl. Conf. Earthq. Eng., Boston, Massachusetts, 2002.

[37] S.K. Jain, W.R. Lettis, D.B. Ballantyne, S.K. Chaubey, U. Dayal, R.K. Goel, A. Goyal, J. Hengesh, P. Malhotra, C.V.R. Murty, P.. Narula, C.K. Saikia, M.P. Singh, K. Vatsa., Preliminary Observations on the Origin and Effects of the January 26 , 2001 Bhuj ( Gujarat , India ) Earthquake, EERI Newsl. 35 (2001).

[38] B. Zhao, F. Taucer, T. Rossetto, Field investigation on the performance of building structures during the 12 May 2008 Wenchuan earthquake in China, Eng. $\begin{array}{llll}\text { Struct. } & 31 & \text { (2009) } & \text { 1707-1723. }\end{array}$ https://doi.org/10.1016/j.engstruct.2009.02.039.

[39] D. Mitchell, R.H. DeVall, M. Saatcioglu, R. Simpson, R. Tinawi, R. Tremblay, Damage to concrete structures due to the 1994 Northridge earthquake, Can. J. Civ. Eng. 22 (1995) 361-377. https://doi.org/10.1139/195-047.

[40] H. Kothari, P. Patel, D. Joshi, Behaviour of the precast portal frames under lateral loading, Asian J. Civ. Eng. 18 (2017) 1059-1076.

[41] I.N. Psycharis, H.P. Mouzakis, Assessment of the seismic design of precast frames with pinned connections from shaking table tests, Bull. Earthq. Eng. $\quad 10 \quad$ (2012) 1795-1817. https://doi.org/10.1007/s10518-012-9372-9.

[42] M. Ercolino, D. Bellotti, G. Magliulo, R. Nascimbene, Vulnerability analysis of industrial RC precast buildings designed according to modern seismic codes, Eng. Struct. 158 (2018) 67-78. https://doi.org/10.1016/j.engstruct.2017.12.005.

[43] C. Casotto, V. Silva, H. Crowley, R. Nascimbene, R. Pinho, Seismic fragility of Italian RC precast industrial structures, Eng. Struct. 94 (2015) 122-136. https://doi.org/10.1016/j.engstruct.2015.02.034.

[44] F. Clementi, A. Scalbi, S. Lenci, Seismic performance of precast reinforced concrete buildings with dowel pin connections, J. Build. Eng. 7 (2016) 224-238. https://doi.org/10.1016/j.jobe.2016.06.013.

[45] P. Negro, D.A. Bournas, F.J. Molina, Pseudodynamic tests on a full-scale 3-storey precast concrete building: Global response, Eng. Struct. 57 (2013)

594-608. https://doi.org/10.1016/j.engstruct.2013.05.047.

[46] H. Sucuoglu, Effect of connection rigidity on seismic response of precast concrete frames, PCI J. 40 (1995) 94-102. https://doi.org/10.15554/pcij.01011995.94.103.

[47] R. Sousa, N. Bastalha, H. Rodrigues, Review of the stratergies for modelling beam-to-column connection in existing precast industrial RC buildings, Congr. Métodos Numéricos Em Eng. (2019) 1-18.

[48] H.H. Ghayeb, H.A. Razak, N.H.R. Sulong, Development and testing of hybrid precast concrete beam-to-column connections under cyclic loading, Constr. Build. Mater. 151 (2017) 258-278. https://doi.org/10.1016/J.CONBUILDMAT.2017.06. 073.

[49] S. Bahrami, M. Madhkhan, Experimental performance of a new precast beam to column connection using hidden corbel, Asian J. Civ. Eng. 18 (2017) 791-805.

[50] L. Shufeng, L. Qingning, Z. Hao, J. Haotian, Y. Lei, J. Weishan, Experimental study of a fabricated confined concrete beam-to-column connection with end-plates, Constr. Build. Mater. 158 (2018) 208216.

https://doi.org/10.1016/J.CONBUILDMAT.2017.10. 025.

[51] P.K. Aninthaneni, R.P. Dhakal, J. Marshall, J. Bothara, Nonlinear Cyclic Behaviour of Precast Concrete Frame Sub-Assemblies With "Dry" End Plate Connection, Structures. 14 (2018) 124-136. https://doi.org/10.1016/j.istruc.2018.03.003.

[52] H. Wang, E.M. Marino, P. Pan, H. Liu, X. Nie, Experimental study of a novel precast prestressed reinforced concrete beam-to-column joint, Eng. Struct. $\quad 156 \quad$ (2018) 68-81. https://doi.org/10.1016/j.engstruct.2017.11.011.

[53] H. Parastesh, I. Hajirasouliha, R. Ramezani, A new ductile moment-resisting connection for precast concrete frames in seismic regions: An experimental investigation, Eng. Struct. 70 (2014) 144-157. https://doi.org/10.1016/J.ENGSTRUCT.2014.04.001.

[54] C. Lu, B. Dong, J. Pan, Q. Shan, A. Hanif, W. Yin, An investigation on the behavior of a new connection for precast structures under reverse cyclic loading, Eng. $\quad$ Struct. $169 \quad$ (2018) 131-140. https://doi.org/10.1016/j.engstruct.2018.05.041.

[55] H.K. Choi, Y.C. Choi, C.S. Choi, Development and testing of precast concrete beam-to-column connections, Eng. Struct. 56 (2013) 1820-1835. https://doi.org/10.1016/j.engstruct.2013.07.021.

[56] S.C. Girgin, I.S. Misir, S. Kahraman, Experimental Cyclic Behavior of Precast Hybrid Beam-Column Connections with Welded Components, Int. J. Concr. Struct. Mater. $11 \quad$ (2017) 229-245. https://doi.org/10.1007/s40069-017-0190-y.

[57] R. Ketiyot, C. Hansapinyo, Seismic performance of 
International Journal of Engineering Research and Technology. ISSN 0974-3154, Volume 13, Number 10 (2020), pp. 2694-2705

(C) International Research Publication House. https://dx.doi.org/10.37624/IJERT/13.10.2020.2694-2705

interior precast concrete beam-column connections with T-section steel inserts under cyclic loading, Earthq. Eng. Eng. Vib. 17 (2018) 355-369.

[58] Q. Yan, T. Chen, Z. Xie, Seismic experimental study on a precast concrete beam-column connection with grout sleeves, Eng. Struct. 155 (2018) 330-344. https://doi.org/10.1016/J.ENGSTRUCT.2017.09.027. 